\title{
PERLINDUNGAN HUKUM BAGI NASABAH PEMEGANG KARTU KREDIT ATAS PEMALSUAN DATA YANG DILAKUKAN OLEH PIHAK MARKETING KARTU KREDIT
}

\section{Rani Apriani}

Fakultas Hukum, Universitas Singaperbangsa Karawang Jl. H.S. Ronggowaluyo Telukjambe Karawang 41361, N E-mail: rani88_fhunsika@yahoo.com

Submitted : 09/11/2018 Reviewed 09/02/2019 Accepted:06/03/2019

\begin{abstract}
Consumer financing is one of the financing models carried out by financial companies, in addition to activities such as leasing, factoring, credit cards, and so on. Today many customers are interested in having a credit card because there are several benefits to using a credit card. However, sometimes to launch a credit card, there are several customer data that are falsified by credit card marketing. This is done to streamline the credit card issuance process. The purpose of writing is expected to not falsify customer data, because it can cause harm to all parties. The method used in this study is the legal sociology approach. Legal protection for credit card holder customers for falsifying data made by credit card marketing can be seen from the regulations governing credit cards, namely Law number 8 of 1999 concerning Consumer Protection, Law Number 10 of 1998 concerning Banking, Bank Regulation Indonesia Number 14/2/ PBI/2012 concerning the Implementation of Card-Based Payment Instruments (APMK). With falsification some data causes losses to customers and banks.
\end{abstract}

Keywords: Credit Card; Consumer Protection; Banking.

Abstrak: Pembiayaan konsumen merupakan salah satu model pembiayaan yang dilakukan oleh perusahaaan finansial, disamping kegiatan seperti leasing, factoring, kartu kredit, dan sebagainya. Saat ini banyak nasabah yang tertarik untuk memiliki kartu kredit sebab terdapat beberapa keuntungan jika memakai kartu kredit. Tetapi terkadang untuk melancarkan mendapatkan kartu kredit, ada beberapa data nasabah yang dipalsukan oleh pihak marketing kartu kredit, ini dilakukan untuk mempelancar proses penerbitan kartu kredit. Tujuan penulisan diharapkan tidak terjadi pemalsuan data nasabah, sebab dapat menyebabkan kerugian bagi semua pihak. Metode penelitian adalah pendekatan sosiologi hukum. Hasilnya adalah perlindungan hukum bagi nasabah pemegang kartu kredit atas 
pemalsuan data yang dilakukan oleh pihak marketing kartu kredit dapat dilihat dari peraturan yang mengatur mengenai kartu kredit yaitu Undang-Undang Nomor 8 Tahun 1999 Tentang Perlindungan Konsumen, Undang-Undang Nomor 10 Tahun 1998 tentang Perbankan, Peraturan Bank Indonesia Nomor 14/2/PBI/2012 tentang Penyelenggaraan Alat Pembayaran Dengan Menggunakan Kartu (APMK). Dengan dipalsukannya beberapa data menyebabkan kerugian bagi nasabah dan bank.

Kata Kunci: Kartu Kredit; Perlindungan Konsumen; Perbankan.

\section{PENDAHULUAN}

Pembiayaan konsumen merupakan salah satu model pembiayaan yang dilakukan oleh perusahaaan finansial, disamping kegiatan seperti leasing, factoring, kartu kredit, dan sebagainya. Target pasar dari model pembiayaan konsumen ini sudah jelas, yaitu para konsumen. Suatu istilah yang dipakai sebagai lawan kata dari produsen. Lembaga pembiayaan yang dapat dijalankan oleh suatu perusahaan pembiayaan dimaksud salah satunya menyebutkan usaha Kartu Kredit. ${ }^{1}$ Kartu Kredit adalah Alat Pembayaran dengan Menggunakan Kartu (APMK) yang dapat digunakan untuk melakukan pembayaran atas kewajiban yang timbul dari suatu kegiatan ekonomi, termasuk transaksi pembelanjaan dan/ atau untuk melakukan penarikan tunai, di mana kewajiban pembayaran pemegang kartu dipenuhi terlebih dahulu oleh acquirer atau penerbit, dan pemegang kartu berkewajiban untuk melakukan pembayaran pada waktu yang disepakati baik dengan pelunasan secara sekaligus (charge card) ataupun dengan pembayaran secara angsuran (menurut Peraturan Bank Indonesia Nomor 11/11/ PBI/2009 tentang Penyelenggaraan Kegiatan Alat Pembayaran Dengan Menggunakan Kar-

1 Dahlan Siamat. 2005. Manajemen Lembaga Keuangan. Jakarta: Lembaga Penerbit Fakultas Ekonomi Universitas Indonesia, hlm. 634. tu, Pasal 1 ayat 2).

Persyaratan untuk mendapatkan kartu kredit, penerbit harus melakukan penilaian atas aspek finansial dari pemohon kartu kredit sehingga tidak setiap anggota masyarakat mempunyai kesempatan untuk memiliki kartu kredit. Berkembangnya peradaban dan gaya hidup masyarakat dalam era modern, ikut meningkatkan aktivitas ekonomi tanpa menghiraukan batas-batas Negara. Teknologi komunikasi berkembang semakin canggih sehingga mempermudah berbagai aktivitas ekonomi dimaksud. Keanekaragaman dan kecanggihan produk barang dan jasa juga merupakan konsekuensi dari globalisasi ekonomi. Berbagai produk jasa yang semula hanya terbatas untuk daerah-daerah tertentu, saat ini sudah dapat dipasarkan di seluruh dunia. Hal ini terbukti dari pemasaran jasa perbankan yang sudah melewati batas wilayah suatu Negara.

Menurut Undang-Undang Nomor 7 Tahun 1992 jo Undang-Undang Nomor 10 Tahun 1998 tentang Perbankan, jasa-jasa yang dapat dilakukan oleh bank umum salah satunya adalah transfer atau pemindahan uang. Fungsi bank dalam menjalankan operasional secara umum adalah menghimpun dana dari masyarakat dan menyalurkannya kembali kepada masyarakat untuk berbagai tujuan atau sebagai financial intermediary atau lembaga 
keuangan. $^{2}$ Selain itu bank dapat melayani berbagai kebutuhan pembiayaan serta melancarkan sistem pembayaran bagi semua sector perekonomian. $^{3}$

Unsur esensial dari kredit bank adalah adanya kepercayaan dari bank sebagai kreditor terhadap nasabah peminjam sebagai debitor. Makna dari kepercayaan tersebut adalah adanya keyakinan dari bank sebagai kreditor bahwa kredit yang diberikan akan sungguhsungguh diterima kembali dalam jangka waktu tertentu sesuai kesepakatan. Untuk setiap penerbitan kartu kredit terdapat beberapa perjanjian yang melibatkan berbagai pihak. Menurut Subekti, "Suatu perjanjian adalah suatu peristiwa di mana seorang berjanji kepada seorang lain atau di mana dua orang itu saling berjanji untuk melaksanakan sesuatu hal". ${ }^{4}$

Asas-asas perjanjian yang terkandung di dalam KUHPerdata sangatlah luas, mencakup asas kebebasan mengadakan perjanjian (partij otonomi), asas konsensualisme (persesuaian kehendak), asas kepercayaan, asas kekuatan mengikat, asas persamaan di depan hukum, asas keseimbangan, asas kepastian hukum, asas moral, asas kepatutan, dan asas kebiasaan. ${ }^{5}$ Asas-asas dimaksud harus dipedomani pihak-pihak yang terlibat dalam setiap perjanjian. Dengan menggunakan sarana kartu kredit, para nasabah dapat melakukan berbagai transaksi dan tidak perlu

2 Sri Susilo dan Tim. 2000. Bank dan Lembaga Keuangan Lain. Jakarta: Salemba Empat, hlm. 4

3 Sentosa Sembiring. 2012. Hukum Perbankan. Edisi Revisi. Bandung: Mandar Maju, hlm. 16

4 Subekti. 2002. Hukum Perjanjian. Cetakan ke-19. Jakarta: Intermasa, hlm. 1

5 Mariam Darus Badrulzaman. 2001. KUHPerdata Buku III, Hukum Perikatan Dengan Penjelasan. Bandung: Alumni, hlm. 108 harus datang dan antri di kantor/bank pemberi jasa, melainkan cukup datang di outlet-outlet yang tersebar hampir di tempat-tempat yang cukup strategis sehingga sangat memudahkan bagi para nasabah untuk menggunakan fiturfitur yang ditawarkan oleh bank pemberi jasa.

Perubahan masyarakat dalam bidang sosial dan ekonomi menyebabkan kebutuhan akan penggunaan sistem pengguna kartu plastik semakin dibutuhkan. Masyarakat semakin menginginkan sistem pelayanan yang lebih efisien dan dapat memberikan kemudahankemudahan dalam melakukan transaksi perbankan, antara lain untuk melakukan penarikan uang tunai, pembayaran tagihan kartu kredit, pembayaran tagihan pulsa dan lainnya. Sistem kerja kartu kredit adalah bekerjanya kartu kredit mulai dari penerbitan, transaksi pembayaran sampai dengan transaksi pembayaran oleh bank dengan melibatkan pihakpihak yang saling berkepentingan. ${ }^{6}$

Saat ini banyak nasabah yang tertarik untuk memiliki kartu kredit, sebab dengan menggunakan kartu kredit maka nasabah bisa melakukan pembayaran dengan cara menyicil dan tidak dikenakan bunga. Akan tetapi dalam mendapatkan kartu kredit tersebut, ada beberapa data nasabah yang dipalsukan oleh pihak marketing kartu kredit agar nasabahnya memiliki kemudahan untuk memperoleh kartu kredit. Misalnya memalsukan data besarnya gaji nasabah. Selain itu hal ini dilakukan untuk memperkaya pihak marketing kartu kredit sebab semakin banyak kartu kredit yang di setujui maka marketing akan mendapatkan bonus yang besar.

Sistem pembayaran secara elektronik ini

6 Kasmir. 2012. Dasar-Dasar Perbankan. Jakarta: Raja Grafindo Persada, hlm. 197 
dapat memberikan kenyaman dengan proses yang lebih cepat, efisien, paperless, waktu yang lebih fleksibel, tanpa perlu hadir di counter bank telah memberikan electronic funds transfer beberapa kelebihan. Namun harus disadari bahwa dengan sifatnya yang unik tersebut perlindungan terhadap nasabah dapat menjadi tidak jelas, dimana pada akhirnya dapat mengakibatkan masalah-masalah yang timbul dari transaksi tersebut. Ketidakefektifan perlindungan konsumen juga menimpa para konsumen pengguna kartu kredit. Konsumen pengguna kartu kredit merupakan pihak yang sering dirugikan akibat kebijakan dalam hal ini klausula baku dari pihak bank yang mengeluarkan kartu kredit. Kerugian yang menimpa pengguna kartu kredit dapat berupa adanya berbagai bentuk pembebanan biaya-biaya yang sebenarnya tidak harus dibayar oleh pengguna kartu kredit. Kenyataan ini menunjukkan bahwa pihak bank memanfaatkan posisi konsumen yang lemah dan menganggap konsumen sangat membutuhkan kartu kredit tersebut, sehingga mereka tidak akan komplain atas tindakan sewenangwenang pihak bank dalam membebankan berbagai biaya kepada konsumen. Bahkan nasabah sering berada dalam pihak yang dirugikan, misalnya transaksi dengan menggunakan kartu kredit, sebagai contoh adanya transaksi yang tidak pernah dilakukan sebelumnya oleh pemilik kartu kredit namun yang terjadi adanya pemberitahuan dari pihak bank mengenai tagihan kartu kredit tersebut, perhitungan kredit limit atau saldo yang salah sehingga pemegang kartu kredit membatalkan transaksi belanja mereka, adanya keluhan dari nasabah mengenai suku bunga yang tidak sesuai pada saat perjanjian, hal ini jelas sangat merugikan nasabah pada saat melakukan transaksi.

Nasabah sebagai konsumen memiliki kedudukan yang lemah, Nasabah hanya bisa mengajukan klaim pada pihak bank. Transaksi dengan menggunakan electronic funds transfer sangat rentan terhadap timbulnya penipuan (fraud) yang antara lain dapat dilakukan oleh nasabah atau pihak yang berhubungan dengan nasabah, pihak bank dalam hal ini adalah pegawai bank itu sendiri maupun dari transmisi telekomunikasi. Melihat penagihan kartu kredit yang dilakukan oleh debt collector menimbulkan heboh pada akhir-akhir ini, banyak kalangan mempermasalahkan cara-cara penagihan yang ditempuh penerbit kartu kredit maupun pihak yang dikuasakannya. Publik menilai bahwa penagihan kartu kredit oleh penerbit, terutama oleh debt collector yang dikuasakannya, dilakukan dengan cara-cara yang tidak terpuji, tidak bertanggung jawab, penuh intimidasi, dan melanggar privasi dari pemegang kartu kredit. Ditinjau dari sudut hukum perdata masalah tanggung jawab tidak dapat dilepaskan dari perjanjian atau undang-undang yang mengaturnya. Untuk perikatan yang dilahirkan dari suatu perjanjian, tidak dipenuhinya perikatan oleh salah satu pihak dapat menyebabkan wanprestasi dan penyelesaiannya didasarkan pada hukum perjanjian (the law of contract). ${ }^{7}$ Berdasar hal tersebut penulis tertarik untuk mengambil judul penelitian mengenai: "Perlindungan Hukum Bagi Nasabah Pemegang Kartu Kredit Atas Pemalsuan Data Yang Dilakukan Oleh Pihak Marketing Kartu Kredit” dengan rumusan masalah: bagaimana perlind-

7 Ranti Fauza Mayana. 2007. Urgensi Pengaturan Product Liability dalam Undang-Undang Desain Industri Indonesia di Era Perdagangan Bebas" dalam "Pembangunan Hukum Bisnis dalam Kerangka Sistem Hukum Nasional, Mengenang 70 Tahun Prof. Dr. Djuhaendah Hasan SH, Gurubesar Fakultas Hukum Universitas Padjadjaran. Bandung: UNPAD, hlm. 117 
ungan hukum bagi nasabah pemegang kartu kredit atas pemalsuan data yang dilakukan oleh pihak marketing kartu kredit? Berdasarkan permasalahan diatas, maka tujuan penelitian dalam tulisan ini yaitu untuk mengetahui dan memahami mengenai perlindungan hukum bagi nasabah pemegang kartu kredit atas pemalsuan data yang dilakukan oleh pihak marketing kartu kredit.

\section{METODE}

\section{Lokasi Penelitian}

Untuk memperoleh informasi atau data yang akurat, maka dipilih lokasi penelitian yaitu di salah satu Bank Swasta yang berlokasi di Kabupaten Karawang. Saat ini terdapat pemalsuan data yang di alami oleh nasabah yang ingin memiliki kartu kredit yang dilakukan oleh pihak marketing kartu kredit. Selain pihak bank sebagai penerbit kartu kredit, penulis juga melakukan penelitian pada pihak debitor yaitu beberapa pemegang dan pengguna kartu kredit yang berdomisili di Kabupaten Karawang. Dengan melakukan penelitian di lokasi tersebut, sangat memudahkan untuk mengakses data demi keakuratan penyusunan penelitian ini.

\section{Jenis dan Sumber Data}

Data yang dikumpulkan adalah data sekunder dan data primer.

1. Data sekunder terdiri dari bahan hukum primer yang berasal dari peraturan perundang-undangan yaitu Kitab UndangUndang Hukum Perdata (Burgelijk Wetbook); Kitab Undang-Undang Hukum Dagang (KUHD); Undang-Undang Nomor 10 Tahun 1998 tentang PerubahanUndang-Undang Nomor 7 Tahun 1992 Tentang Perbankan; Undang-undang Nomor 8 Tahun 1999 tentang Perlindungan Konsumen, Peraturan Bank Indonesia
Nomor 14/2/PBI/2012 Tentang Penyelenggaraan Alat Pembayaran Dengan Menggunakan Kartu, Peraturan Perundang-undangan yang berkaitan dengan pencantuman klausula baku pada perjanjain dalam kartu kredit; dan bahan hukum sekunder yaitu literatur, dokumen berupa formulir permohonan pengajuan kartu kredit.

2. Data primer yang diperoleh langsung dari lapangan dengan cara melakukan wawancara kepada kreditor yang terdiri dari Bank Swasta yang berada di Kabupaten Karawang, pihak debitor yaitu Para Pemegang dan Pengguna Kartu Kredit yang berdomisili di Kabupaten Karawang,

\section{Teknik Pengumpulan Data}

Untuk memperoleh data yang dibutuhkan guna melengkapi penelitian yang dilakukan, maka dipergunakan teknik pengumpulan data yang terbagi atas:

1. Wawancara adalah suatu teknik pengumpulan data primer dengan mengajukan pertanyaan langsung kepada responden, yaitu dari pihak kreditur yaitu Bank Swasta yang berada di Kabupaten Karawang serta kepada Pemegang dan pengguna kartu kredit yang berdomisili di kabupaten Karawang.

2. Studi pustaka merupakan jenis data sekunder yang digunakan unutuk membantu proses penelitian, yaitu dengan mengkaji dan menganalisis literatur dan peraturan perundang-undangan, serta datum lainnya yang berkaitan dengan masalah yang dibahas dalam penelitian ini.

\section{Pendekatan dan Jenis Penelitian}

Pendekatan penelitian adalah pendekatan sosiologi hukum (Socio-Legal Approach) karena 
permasalahan yang diteliti ini didekati dari masyarakat selaku debitor dan kreditor, hukum, perbankan, spesifikasi penelitian yang digunakan berupa penelitian deskriptif yang artinya prosedur pemecahan masalah yang diteliti dengan menggambarkan objek dan subjek hukum pada saat sekarang berdasarkan fakta-fakta yang ada.

\section{Populasi dan Sampel}

Populasi dan Sampel Populasi dalam penelitian ini meliputi Bank Swasta sebagai kreditor, serta masyarakat pemegang dan penguna kartu kredit sebagai debitor yang berdomisii di Karawang, sedangkan sampel dalam penelitian ini ditetapkan dengan teknik sampling random yaitu dengan cara menetapkan jumlah kriteria sampel yang ditetapkan oleh peneliti dengan jumlah yang terbatas. Sampel terdiri dari kreditor bank, yaitu Bank Swasta yang berada di Kabupaten Karawang serta pemegang dan pengguna kartu kredit yang berdomisili di kabupaten Karawang yang terdiri dari 30 orang pemegang dan pengguna kartu kredit aktif, dan 20 orang pemegang dan pengguna kartu pasif.

\section{Analisis Data}

Metode analisis data yang digunakan adalah metode kualitatif, yaitu analisis yang memadukan data berupa hasil pengamatan, wawancara, bahan tertulis berupa buku-buku terkait dengan penelitian ini, formulir pengajuan kartu kredit, yang kemudian dianalisis secara deskriptif yang akan memberikan gambaran yang menyeluruh mengenai permasalahan yang diteliti, mencari pemecahan, dan menarik kesimpulan, maka dapat diperoleh suatu hasil yang menggambarkan bagaimana perlindungan hukum bagi nasabah pemegang kartu kredit apabila terjadi pelanggaran klausula baku kartu kredit.

\section{ANALISIS DAN PEMBAHASAN Perlindungan Hukum Bagi Nasabah Pe- megang Kartu Kredit Atas Pemalsuan Data Yang Dilakukan Oleh Pihak Market- ing Kartu Kredit}

Hubungan antara pelaku usaha dan konsumen sering terdapat ketidaksetaraan di antara keduanya. Konsumen biasanya berada dalam posisi yang lemah, sehingga sering terjadi ketidakseimbangan antara pelaku usaha yang merasa mempunyai posisi yang lebih kuat daripada konsumen. Misalnya, perlunya perlindungan oleh hukum bagi pemegang kartu kredit selaku konsumen menjadi sangat penting karena secara faktual kedudukan antara para pihak seringkali tidak seimbang. Para pelaku usaha akan mencari keuntungan yang setinggi-tingginya sesuai dengan prinsip ekonomi. Dalam rangka mencapai untung yang setingi-tingginya itu, para pelaku usaha harus bersaing antar sesama mereka dengan perilaku bisnisnya sendiri-sendiri yang dapat merugikan pemegang kartu kredit, misalnya memberikan syarat dan ketentuan yang mudah untuk mendapatkan kartu kredit, sehingga pemegang kartu merasa tertarik untuk membuatnya. Namun kemudian pelaku usaha akan memberikan bunga serta denda yang tinggi bagi pemegang kartu. Hubungan hukum yang terjadi antara penerbit dan pemegang kartu, akan menimbulkan benturan-benturan yang akan merugikan salah satu pihak. Oleh karena itu diperlukan peraturan hukum yang berlaku bagi para pihak dalam bentuk peraturan perundang-undangan Di dalam ranah perlindungan hukum terhadap pemegang kartu kredit, terdapat beberapa peraturan perundang-undangan yang dapat dijadikan dasar hukum untuk mencegah pelanggaran hukum terhadap pemegang kartu kredit, maupun sebagai instrumen hukum dalam meny- 
elesaikan berbagai permasalahan yang timbul akibat penggunaan kartu kredit. Di dalam peraturan perundang-undangan, Undang-Undang Nomor 8 Tahun 1999 tentang Perlindungan Konsumen, Undang-Undang Nomor 7 Tahun 1992 tentang Perbankan, sebagaimana telah diubah dengan Undang-Undang Nomor 10 Tahun 1998, dapat menjadi dasar bagi perlindungan hukum terhadap pemegang kartu kredit di Indonesia. Selain itu, terdapat peraturan perundang-undangan lainnya di bawah undang-undang yang dapat dijadikan dasar hukum bagi perlindungan hukum terhadap pemegang kartu kredit di Indonesia saat ini, salah satunya adalah Peraturan Bank Indonesia Nomor 14/2/PBI/2012 tentang Penyelenggaraan Alat Pembayaran Dengan Menggunakan Kartu (APMK).

\section{Undang-Undang Nomor 8 Tahun 999 Ten- tang Perlindungan Konsumen}

Lahirnya UUPK memuat peraturan-peraturan hukum yang memberikan perlindungan kepada konsumen. Diundangkannya UUPK guna menyeimbangkan daya tawar konsumen terhadap pelaku usaha dan mendorong pelaku usaha untuk bersikap jujur dan bertanggung jawab dalam menjalankan kegiatannya. Lahirnya UUPK diharapkan menjadi payung hukum (umbrella rule) di bidang konsumen dengan tidak menutup kemungkinan terbentuknya peraturan perundang-undangan lain yang materinya memberikan perlindungan hukum terhadap konsumen, ${ }^{8}$ serta mendorong pelaku usaha untuk bersikap jujur serta bertanggung jawab dalam menjalankan usahanya. Pengaturan melalui UUPK yang sangat terkait dengan perlindungan hukum bagi pe-

8 Erman Rajagukguk, 2000, Hukum Perlindungan Konsumen, Bandung: CV Mandar Maju, hlm. 6. megang kartu kredit adalah mengenai klausula baku. Di dalam kepustakaan ekonomi dikenal istilah konsumen akhir dan konsumen antara. Konsumen akhir adalah pengguna atau pemanfaat akhir dari suatu produk, sedangkan konsumen antara adalah konsumen yang menggunakan suatu produk sebagai bagian dari proses suatu produk lainnya. Pengertian konsumen dalam UUPK ini adalah konsumen akhir.

Pemegang kartu kredit merupakan konsumen akhir, karena mereka memanfaatkan kartu kredit guna membeli barang/jasa selain untuk menarik uang tunai. Karena itulah UUPK dapat dijadikan dasar peraturan yang memberikan perlindungan hukum bagi pemegang kartu kredit di Indonesia. Perlindungan konsumen yang dimaksud dalam UUPK mempunyai cakupan yang luas meliputi bagaimana seorang konsumen mendapatkan barang atau jasa serta akibat dari pemakaian barang atau jasa tersebut. Dalam hal ini perlindungan bagi pemegang kartu kredit mulai dari bagaimana kartu kredit tersebut didapatkan atau proses terbitnya kartu kredit sampai dengan akibat penggunaannya apakah sesuai dengan kesepakatan atau tidak.

Perlindungan Konsumen di Indonesia diselenggarakan sebagai usaha bersama berdasarkan lima Asas Pembangunan Nasional sebagaimana terdapat di dalam Pasal 2 UUPK, yaitu:

1. Asas Manfaat, penerapan UUPK harus memberikan manfaat yang sebesar-besarnya kepada kedua pihak, yaitu penerbit dan pemegang kartu kredit. Sehingga tidak ada satu pihak yang kedudukannya lebih tinggi dibanding pihak lainnya. Kedua belah pihak harus memperoleh hak-haknya secara seimbang. Di dalam 
melakukan transaksi dengan menggunakan kartu kredit, pemegang kartu dapat meningkatkan pengetahuan mengenai kartu kredit, mengenai hak dan kewajiban bagi kedua belah pihak agar dalam pelaksanaannya tidak terjadi penyimpangan;

2. Asas Keadilan, partisipasi seluruh rakyat dapat diwujudkan secara maksimal dan memberikan kesempatan kepada konsumen dan pelaku usaha untuk memperoleh haknya dan melaksanakan kewajiban secara adil. Asas ini jika diterapkan pada perlindungan hukum bagi pemegang kartu kredit, maka antara penerbit dan pemegang kartu melaksanakan hak dan kewajiban secara adil. Apa yang menjadi hak penerbit, akan menimbulkan kewajiban bagi pemegang kartu, begitu pula sebaliknya;

3. Asas Keseimbangan, memberikan keseimbangan antara kepentingan pemegang kartu, pelaku usaha dan pemerintah dalam arti material dan spiritual. Asas keseimbangan konsumen merupakan asas yang melatarbelakangi perlunya perlindungan terhadap pemegang kartu kredit. Perjanjian penerbitan kartu kredit lahir dari asas kebebasan berkontrak. Asas kebebasan berkontrak ini memberikan kebebasan para pihak untuk menentukan sendiri isi, bentuk dan dengan siapa membuat perjanjian asal tidak bertentangan dengan undang-undang, ketertiban umum dan kesusilaan;

4. Asas Keamanan dan Keselamatan Konsumen, memberikan jaminan atas keamanan dan keselamatan kepada konsumen dalam penggunaan, pemakaian dan pemanfaatan barang dan/atau jasa yang dikonsumsi atau digunakan. Asas ini jika diterapkan dalam perjanjian penggunaan kartu kredit, bahwa pemegang kartu akan merasa nyaman dan aman selama menggunkan fasilitas kartu kredit dari penerbit. Jika terjadi penyimpangan-penyimpangan pada perjajian kartu kredit maka diselesaikan berdasarkan klausulaklausula yang terdapat pada perjanjian;

5. Asas Kepastian Hukum, Asas ini dimaksudkan agar baik pelaku usaha maupun konsumen mentaati hukum dan memperoleh keadilan dalam penyelenggaraan perlindungan konsumen, serta negara menjamin kepastian hukum. Di dalam rangka menciptakan hubungan yang sehat serta menciptakan kegiatan usaha yang adil antara produsen dan pelaku usaha maka UUPK memberikan hak kepada konsumen dan membebankan kewajiban serta larangan kepada produsen. Berdasarkan analisis terhadap Pasal 4 UUPK, tidak terdapat perlindungan bagi pemegang kartu kredit secara penuh dalam melakukan berbagai transaksi. Pemegang kartu yang melakukan transaksi secara langsung akan berbeda dengan transaksi yang dilakukan secara tidak langsung. Misalnya membeli barang melalui internet (toko online). Pemegang kartu tidak dapat menjamin keamanan data kartu kredit, tidak dapat mengidentifikasi secara langsung barang yang akan dibelinya, dan informasi yang tidak jelas baik mengenai produk maupun informasi alamat yang benar dari penjual karena hanya mendapatkan gambaran dari penjual secara tidak langsung (internet). Terdapat barang-barang tertentu yang memerlukan tidak hanya gambaran serta penjelasan dari penjual. Misalnya membeli parfume, yang harus dicoba dan dibuktikan secara langsung keasliannya. Sehingga, jika terdapat permasalahan dalam melakukan 
transaksi, seperti barang yang diterima tidak sesuai dengan apa yang dipesan atau barang tidak sampai kepada pembeli, maka pembeli akan merasa dirugikan dan kesulitan untuk melacak data penjual.

Di dalam hak-hak konsumen yang diatur dalam UUPK hanya terbatas pada transaksi perdagangan yang dilakukan secara langsung, tidak mengatur bagaimana hak-hak konsumen jika transaksi dengan menggunakan kartu kredit secara tidak langsung. Perlindungan difokuskan hanya pada sisi konsumen serta sisi produk yang diperdagangkan. Sedangkan perlindungan dari sisi pelaku usaha seperti, informasi tentang identitas perusahaan pelaku usaha serta jaminan kerahasiaan data-data milik konsumen belum diatur oleh UUPK, padahal hak-hak tersebut sangat penting untuk diatur untuk keaman konsumen dalam bertransaksi.

UUPK juga belum melindungi pemegang kartu yang melakukan transaksi dengan penjual atau pelaku usaha diluar negeri. Hal ini terlihat dalam Pasal 1 Ayat (3) UUPK. Berdasarkan Pasal 1 Ayat (3) UUPK, pengaturan mengenai pelaku usaha hanyalah yang berada dalam wilayah hukum Republik Indonesia. Sedangkan dalam melakukan transaksi dengan kartu kredit, pemegang kartu dapat melakukan transaksi diluar wilayah hukum Indonesia, misalnya belanja melalui internet atau melakukan transaksi ketika berada di luar wilayah hukum Republik Indonesia.

Perusahaan penerbit dalam memberikan pelayanan berupa penerbitan kartu kredit harus sesuai dengan apa yang mereka tawarkan baik dari maksimal fasilitas kredit, bunga, denda yang diberikan, hak dan kewajiban yang seimbang bagi kedua belah pihak yang biasanya sudah terdapat dalam perjanjian kredit dalam bentuk kontrak baku (standart contract). Perjanjian baku merugikan salah satu pihak yaitu konsumen, karena isi serta syarat-syarat telah dipersiapkan oleh pihak penerbit, sehingga mereka tidak mengetahui secara jelas, walaupun mereka mengetahui isi perjanjian tersebut namun tidak mengetahui bagaimana akibat hukumnya, karena itu diperlukan adanya penjelasan mengenai isi perjanjian tersebut. Hal inilah yang melatarbelakangi UUPK untuk memberikan pengaturan mengenai klausula baku.

Pasal 18 Ayat (1) UUPK pada dasarnya tidak melarang pelaku usaha untuk membuat perjanjian yang memuat klausula baku, sepanjang klausula tersebut tidak mencantumkan hal-hal yang dilarang namun hanya membatasi pelaku usaha dalam pencantuman klausula baku yang mengarah kepada klausula eksonerasi. Artinya, klausula baku adalah klausula yang dibuat sepihak oleh pelaku usaha, tetapi isinya tidak boleh mengarah pada klausula eksonerasi. Pasal 18 Ayat (1) butir huruf a sampai dengan huruf h merupakan klausula eksonerasi dalam perjanjian standar antara produsen dan konsumen yaitu pembatasan dan penghapusan tanggung jawab dari pelaku usaha. Klausula eksonorasi membebaskan tanggung jawab seseorang pada akibat hukum yang terjadi karena kurangnya kewajiban yang diharuskan oleh perundangundangan. Klausula baku yang melanggar ketentuan Pasal 18 Ayat (1) butir huruf a sampai dengan huruf $\mathrm{h}$ menjadi batal demi hukum (Pasal 18 Ayat (3) UUPK).

Berdasarkan analisis di atas, ada beberapa kelemahan UUPK dalam memberikan perlindungan hukum kepada konsumen khususnya pemegang kartu kredit, yaitu:

1. UUPK hanya mengatur mengenai kepentingan konsumen baru terbatas pada upaya untuk sekedar melarang dan mem- 
berikan sanksi kepada pelaku usaha tanpa memberikan hak kepada konsumen yang dirugikan untuk mendapatkan kompensasi atau ganti rugi atas kerugian yang dideritanya. Jadi UUPK hanya mengatur kepentingan konsumen pada umumnya dari sisi produsen atau pelaku usaha. Sementara dari sisi lain yang terpenting, hak-hak konsumen terabaikan;

2. UUPK tidak memberikan jaminan tentang hak publik atas informasi (public access to information) secara luas mengenai kartu kredit secara benar, jelas dan jujur mengenai berbagai hak dan kewajiban kedua belah pihak. Selain itu pemegang kartu juga berhak untuk didengar pendapat serta keluhan atas fasilitas kartu kreditnya.

Di dalam penjelasan UUPK, menerangkan bahwa UUPK pada dasarnya bukan merupakan awal dan akhir dari hukum yang mengatur tentang perlindungan konsumen, sebab perlindungan konsumen akan selalu mengalami dinamika dan perkembangan yang berbanding lurus dengan dinamika dan perkembangan yang ada di masyarakat serta sampai pada terbentuknya sebuah undangundang yang materinya dapat melindungi kepentingan konsumen secara keseluruhan.

\section{Undang-Undang Nomor 10 Tahun 1998 tentang Perbankan}

UUP merupakan salah satu dari dasar hukum penyelenggaraan kegiatan kartu kredit di Indonesia, karena bank adalah pihak yang menerbitkan kartu kredit. Pengertian bank berdasarkan Pasal 1 angka 2 Undang-Undang Nomor 7 Tahun 1992 sebagaimana telah diubah dengan Undang-Undang Nomor 10 Tahun 1998 tentang Perbankan, bank adalah badan usaha yang menghimpun dana dari ma- syarakat dalam bentuk kredit dan atau bentukbentuk lainnya dalam rangka meningkatkan taraf hidup rakyat banyak.

Bank sebagai kreditur memberikan pinjaman serta berbagai fasilitas bagi para nasabahnya. Nasabah bank adalah pihak yang menggunakan jasa bank, terdiri dari nasabah penyimpan dan nasabah debitur. Nasabah penyimpan adalah nasabah yang menempatkan dananya dalam bentuk simpanan berdasarkan perjanjian bank dengan nasabah yang bersangkutan, sedangkan nasabah debitur adalah nasabah yang rnemperoleh fasilitas kredit atau pembiayaan berdasarkan yang berdasarkan prinsip syariah atau yang dipersarnakan dengan itu berdasarkan perjanjian bank dengan nasabah yang bersangkutan. Pemegang kartu kredit merupakan nasabah debitur, karena mendapatkan fasilitas berupa kartu kredit.

Pasal 6 huruf 1 Undang-Undang Perbankan menyatakan bahwa usaha kartu kredit merupakan salah satu bentuk usaha yang dapat dilakukan oleh bank. Kartu kredit sebagai salah satu bentuk usaha yang dilakukan oleh bank, maka prinsip 5C atau "the five C's principles" yang digunakan untuk menilai mengevaluasi calon nasabah kredit juga berlaku pada usaha kartu kredit. Prinsip 5C tersebut adalah character, capacity, capital, collateral dan condition.

Hubungan antara bank dengan nasabah dalam menjalankan kegiatan usahanya, menimbulkan dua sisi tanggung jawab, yaitu kewajiban yang terletak pada bank itu sendiri dan kewajiban nasabah sebagai akibat hubungan hukum dengan bank. Hak dan kewajiban antara bank dengan nasabah diwujudkan dalam suatu bentuk prestasi yang telah ditentukan dalam perjanjian yang dibuat antara bank dengan nasabah. Hubungan hukum antara bank dengan nasabah akan menimbulkan hak 
dan kewajiban.

Kewajiban bank terhadap nasabah di antaranya sebagai berikut:

1. Kewajiban bank untuk tetap menjaga rahasia keuangan nasabah, yaitu "segala sesuatu yang berhubungan dengan keterangan mengenai nasabah penyimpan dan simpanannya (Pasal 1 angka 28 UUP), dan Pasal 40 "Bank wajib merahasiakan keterangan mengenai nasabah penyimpan dan simpanannya, kecuali dalam hal sebagaimana dimaksud dalam Pasal 41, Pasal 41A, Pasal 42, Pasal 43, Pasal 44, dan Pasal 44 A;

2. Kewajiban bank untuk mengamankan dana nasabah, yang dalam kaitannya dengan tanggung jawab mengamankan uang nasabah perlu mengadakan suatu jaminan simpanan uang pada bank;

3. Kewajiban untuk menerima sejumlah uang dari nasabah, dengan mengingat fungsi utama perbankan sebagai penghimpun dana masyarakat, maka bank berkewajiban untuk menerima sejumlah uang dari nasabah atas produk perbankan yang dipilih, seperti tabungan dan deposito;

4. Kewajiban untuk melaporkan kegiatan perbankan secara transparan kepada masyarakat. Adapun kewajiban yang dimaksud adalah bank wajib melaporkan kegiatan banknya kepada masyarakat secara transparan, artinya selama kurun waktu tertentu;

5. Kewajiban bank untuk mengetahui secara mendalam tentang nasabahnya. Adapun yang dimaksud dengan kewajiban ini adalah bank wajib meminta keterangan bukti diri dari nasabah, dengan maksud mencegah hak-hal yang tidak diinginkan di kemudian hari apabila seseorang akan mengambil atau menarik uangnya dari bank yang bersangkutan.

Ketentuan yang dapat menjadi dasar perlindungan bagi nasabah bank seperti diuraikan di atas, perlindungan keamanannya lebih mengarah pada operasional kegiatan perbankan secara luar dan umum. Oleh karenanya diperlukan adanya perlindungan yang bersifat pribadi dan langsung kepada nasabah dan lebih khusus. Artinya, perlindungan lebih dulu datang dari nasabah itu sendiri karena memahami suatu produk jasa perbankan yang ditawarkan.

Berdasarkan analisis di atas UndangUndang Perbankan dapat dijadikan dasar penyelenggaraan usaha kartu kredit sebagai alat pembayaran oleh bank. UUP memuat ketentuan-ketentuan kredit pada umumnya, yang berarti segala ketentuan yang ada dalam perjanjian kredit juga berlaku terhadap perjanjian kartu kredit. Undang-undang tersebut tidak mengatur secara lebih rinci mengenai bagaimana proses penerbitan dan penggunaan kartu kredit sebagai alat pembayaran serta bagaimana perlindungan hukum bagi pemegang kartu kredit.

Peraturan Bank Indonesia Nomor 14/2/ PBI/2012 tentang Penyelenggaraan Alat Pembayaran Dengan Menggunakan Kartu (APMK)

Perubahan PBI No.11/11/PBI/2009 menjadi PBI 14/2/PBI/2012 dilatarbelakangi oleh pertimbangan penerapan prinsip kehatihatian, aspek perlindungan bagi pemegang kartu, manajemen risiko pemberian kredit dalam penyelenggaraan kartu kredit, standar keamanan bagi teknologi serta aspek peningkatan APMK. Sebagai aturan pelaksana dari PBI tersebut Bank Indonesia mengeluarkan Surat Edaran Bank Indonesia (SEBI) mengenai Alat Pembayaran Menggunakan Kartu, 
yaitu Surat Edaran Nomor 14/17/DASP tentang perubahan atas Surat Edaran Bank Indonesia Nomor 11/10/DASP. Sebagai upaya penerapan prinsip perlindungan nasabah, penerbit APMK diwajibkan oleh PBI APMK serta peraturan pelaksananya memperketat sejumlah ketentuan mengenai kartu kredit, yang meliputi:

1. Pengaturan mengenai batas maksimum suku bunga kartu kredit.

Besarnya bunga kartu kredit ditetapkan oleh Bank Indonesia sebesar 3\% perbulan. Dalam penetapan bunga, melarang praktek bunga berbunga alias bunga majemuk. Pada praktek bunga berbunga ini, nilai pokok utang naik terus setiap bulan karena tambahan-tambahan 54 berupa denda (charges), materai dan iuran (fee) yang seharusnya tidak boleh dikenakan bunga, karena nilai pokok utang yang seharusnya sama di bulan berikutnya sudah kena tambahan fee/charge maupun materai. Nilai pokok utang yang baru inilah kemudian yang dikalikan lagi dengan bunga kartu kredit per bulan.Berdasarkan Surat Edaran Bank Indonesia No. 14/34/ DASP tanggal 27 November 2012 yang akan berlaku tanggal 1 Januari 2013, bahwa:

a. Batas maksimum suku bunga kartu kredit yang wajib diterapkan oleh penerbit kartu kredit adalah sebesar 2,95\% (dua koma sembilan puluh lima persen) per bulan atau 35,40\% (tiga puluh lima koma empat puluh persen) per tahun;

b. Batas maksimum suku bunga kartu kredit sebagaimana dimaksud pada angka 1 berlaku baik untuk transaksi pembelanjaan maupun transaksi tarik tunai; c. Bank Indonesia dapat mengubah batas maksimum suku bunga kartu kredit sebagaimana dimaksud pada angka 1 dengan mempertimbangkan, antara lain :

1) Indikator perekonomian seperti $\mathrm{BI}$ rate;

2) Struktur biaya kartu kredit yang meliputi biaya dana (cost of fund), biaya operasional dan pengelolaan risiko kredit oleh Penerbit (risk premium); dan/ atau;

3) Praktek suku bunga yang dikenakan oleh Penerbit.

2. Pengaturan persyaratan pemberian fasilitas kredit dalam rangka menerapkan manajemen risiko.

a. Kepemilikan kartu utama, usia pemegang kartu minimal harus berumur 21 tahun atau telah kawin dan minimum berusia 17 tahun atau telah kawin untuk kartu tambahan;

b. Pendapatan minimum Rp3 juta per bulan;

c. Maksimal plafon kredit adalah tiga kali pendapatan per bulan dan penerapannya berlaku secara industri;

d. Calon pemegang kartu yang pendapatan per bulannya kurang dari Rp10 juta dikenakan pembatasan plafon serta pembatasan perolehan kartu kredit maksimum dari dua penerbit;

e. Calon pemegang kartu yang pendapatan per bulannya Rp10 juta ke atas tidak dikenakan pembatasan jumlah plafon dan kartu dari dua penerbit sehingga analisis kredit sepenuhnya diserahkan kepada Bank.

3. Pengaturan prinsip kehati-hatian serta perlindungan bagi pemegang kartu. 
Prinsip kehati-hatian dilakukan dengan cara penyeragaman pola perhitungan bunga kartu kredit, pengenaan biaya denda serta kewajiban menyampaikan informasi kepada pemegang kartu. Informasi tersebut wajib menggunakan Bahasa Indonesia yang jelas dan mudah dimengerti, ditulis dalam huruf dan angka yang mudah dibaca oleh calon pemegang kartu. Selain itu penerbit juga menyediakan sarana dan nomor telepon yang dapat secara mudah digunakan dan/atau dihubungi oleh calon pemegang kartu dan pemegang kartu dalam rangka melakukan verifikasi kebenaran segala fasilitas yang ditawarkan dan/atau informasi yang disampaikan oleh penerbit.

4. Pengaturan kerjasama dengan pihak lain dalam rangka penagihan hutang.

Bank Indonesia telah mengeluarkan Surat Edaran Bank Indonesia Nomor 14/17 DASP tertanggal 7 Juni 2012 perihal Penyelenggaraan Kegiatan Alat Pembayaran Dengan Menggunakan Kartu, yang salah satu isinya adalah mengatur mengenai ketentuan mengenai jasa penagihan kartu kredit (debt collector). Di dalam melakukan kerjasama dengan pihak penagih hutang, pihak penerbit kartu kredit wajib memperhatikan dan memenuhi ketentuanketentuan sebagai berikut:

a. Penagihan kartu kredit dapat dilakukan oleh penerbit kartu kredit dengan menggunakan tenaga penagihan sendiri atau tenaga penagihan dari perusahaan penyedia jasa penagihan;

b. Penagihan kartu kredit baik menggunakan tenaga penagihan sendiri atau tenaga penagihan dari perusahaan penyedia jasa penagihan, penerbit wajib memastikan bahwa tenaga yang melakukan penagihan telah memperoleh pelatihan yang memadai terkait dengan tugas penagihan dan etika penagihan sesuai ketentuan yang berlaku. Identitas setiap tenaga penagihan dipersiapkan dengan baik oleh penerbit kartu kredit. Tenaga penagihan dalam melaksanakan penagihan mematuhi etika penagihan. Penagihan hutang kartu kredit dilarang dilakukan dengan ancaman, kekerasan dan/atau tindakan yang bersifat mempermalukan pemegang kartu kredit. Penagih juga tidak boleh melakukan tekanan secara fisik maupun verbal. Penagihan dilakukan langsung kepada pemegang kartu kredit tidak boleh dilakukan kepada pihak lain. Dalam melakukan penagihan hutang melalui sarana komunikasi (telepon) dilarang dilakukan secara terusmenerus yang bersifat mengganggu. Penagihan dilakukan dalam waktu pukul 08.00 sampai dengan pukul 20.00 di wilayah waktu setempat pemegang kartu, kecuali diperjanjikan secara khusus. Jadi dalam melakukan penagihan hutang pihak penagih harus benar-benar memperhatikan etika penagihan kepada pemegang kartu. Penerbit kartu kredit juga harus memastikan bahwa pihak lain yang menyediakan jasa penagihan yang bekerjasama dengan penerbit juga mematuhi etika penagihan yang ditetapkan oleh asosiasi penyelenggara APMK. Jika penagihan kartu kredit dilakukan menggunakan tenaga penagihan dari perusahaan penyedia jasa penagihan, maka 
selain berlaku ketentuan sebagaimana dimaksud pada huruf $b$, juga berlaku ketentuan sebagai berikut:

1) Penagihan kartu kredit menggunakan tenaga penagihan dari perusahaan penyedia jasa penagihan, hanya dapat dilakukan jika kualitas tagihan kartu kredit dimaksud telah termasuk dalam kualitas macet berdasarkan kriteria kolektibilitas sesuai ketentuan Bank Indonesia yang mengatur mengenai kualitas kredit;

2) Kerjasama antara penerbit kartu kredit dengan perusahaan penyedia jasa penagihan wajib dilakukan sesuai ketentuan Bank Indonesia yang mengatur mengenai prinsip kehati-hatian bagi bank umum yang melakukan penyerahan sebagian pelaksanaan pekerjaan kepada pihak lain, dan peraturan perundangundangan yang berlaku;

3) Penerbit kartu kredit wajib menjamin kualitas pelaksanaan penagihan kartu kredit oleh perusahaan penyedia jasa penagihan sama dengan jika dilakukan sendiri oleh penerbit kartu kredit.

Dampak negatif dari adanya pihak penagih hutang disebabkan oleh empat hal, yaitu:

a) Pemasaran kartu kredit dalam bentuk Kredit Tanpa Agunan (KTA);

b) Penggunaan kartu kredit secara konsumtif;

c) Meningkatnya jumlah NPL pertahun; d) Adanya izin penggunaan jasa penagih hutang oleh Bank Indonesia, namun tidak diikuti adanya kejelasan Instansi Pemerintah mana yang membina jasa penagih hutang tersebut sebagai wujud pertanggung jawaban negara kepada warganegaranya, akan terjadi perulangan-perulangan yang sama di masa yang akan datang.

Adanya pihak penagih hutang secara struktural dalam hubungan perdata antara pihak bank dan pemegang kartu (nasabah) dipandang sebagai itikad tidak baik dari pelaku usaha. Seorang pemegang kartu yang datang ke bank untuk mengklarifikasi besarnya jumlah tagihan hutang kartu kredit merupakan suatu itikad baik. Namun biasaya tidak ada timbal balik dari pihak bank/penerbit Berdasarkan hukum perjanjian, tidak ada hubungan hukum antara pemegang kartu kredit dengan penagih hutang. Jika bank melibatkan nasabah, maka seharusnya dari sejak awal diinformasikan dan dituangkan dalam klausul baku kartu kredit. Tidak diinformasikannya hal ini kepada pemegang kartu merupakan itikad tidak baik dari bank sebagai penerbit.

5. Pengaturan dalam rangka peningkatan pengamanan.

Peningkatan keamanan bagi pemegang kartu dalam melakukan transaksi, maka pihak penerbit wajib untuk mengimplementasikan mengenai PIN paling kurang enam digit sebagai sarana verifikasi dan autentifikasi. Transaction alert kepada 
pemegang kartu kredit dengan menggunakan teknologi layanan pesan singkat (short message service/sms) atau sarana lainnya berdasarkan pilihan pemegang kartu kredit.

Penegasan kewenangan Bank Indonesia dalam perizinan serta penegasan sanksi dalam penyelenggaraan APMK. PBI memberikan sanksi bagi pelanggaran yang dilakukan pihak penyelenggara APMK berupa teguran, denda, penghentian sementara seluruh kegiatan serta mencabut izin penyelenggaraan APMK. Peraturan Bank Indonesia hanya mengatur tentang cara melakukan pembayaran dengan menggunakan kartu kredit. Peraturan tersebut berlaku bagi penerbit yang melakukan usaha tersebut yaitu bank atau lembaga pembiayaan. Namun dalam praktiknya bank mempunyai peraturan tersendiri dalam usaha penerbitan kartu kredit sehingga mereka tidak mengikuti peraturan yang telah ditentukan. Peraturan ini juga belum menjelaskan bagaimanakah sanksi yang tegas bagi pihak penerbit yang menggunakan jasa penagih hutang. Jadi pada dasarnya Peraturan Bank Indonesia ini belum bisa memberikan perlindungan yang maksimal bagi pemegang kartu kredit.

Dari uraian diatas maka dapat dilihat bahwa berbagai peraturan yang mengatur mengenai kartu kredit, tidak ada satu pun dari peraturan tersebut yang mengatur secara khusus mengenai perlindungan hukum terhadap pemegang kartu kredit.

\section{PENUTUP}

\section{Kesimpulan}

Perlindungan hukum bagi nasabah pemegang kartu kredit apabila terjadi pelang- garan kartu kredit dapat dilihat dari peraturan yang mengatur mengenai kartu kredit yaitu Undang-Undang Nomor 8 Tahun 1999 Tentang Perlindungan Konsumen, UndangUndang Nomor 10 Tahun 1998 tentang Perbankan, Peraturan Bank Indonesia Nomor 14/2/PBI/2012 tentang Penyelenggaraan Alat Pembayaran Dengan Menggunakan Kartu (APMK).

\section{Saran}

Upaya perlindungan hukum terhadap nasabah kartu kredit dapat terwujud dengan adanya sosialisasi informasi mengenai peraturan yang terkait mengenai kartu kredit seperti Undang-Undang Perlindungan Konsumen oleh pemerintah khususnya kepada pengguna kartu kredit, sehingga hubungan hukum antara pihak bank dengan nasabah kartu kredit akan berjalan dengan baik karena kedua belah pihak saling mengetahui akan hak dan kewajibannya masing-masing.

\section{BIBLIOGRAFI}

Badrulzaman, Mariam Darus. 2001. KUH Perdata Buku III, Hukum Perikatan Dengan Penjelasan. Bandung: Alumni.

Kasmir. 2012. Dasar-Dasar Perbankan. Jakarta: Raja Grafindo Persada.

Mayana, Ranti Fauza. 2007. Urgensi Pengaturan Product Liability dalam Undang-Undang Desain Industri Indonesia di Era Perdagangan Bebas" dalam "Pembangunan Hukum Bisnis dalam Kerangka Sistem Hukum Nasional, Mengenang 70 Tahun Prof.Dr. Djuhaendah Hasan SH, Gurubesar Fakultas Hukum Universitas Padjadjaran. Bandung: UNPAD.

Rajagukguk, Erman. 2000. Hukum Perlindungan Konsumen. Bandung: CV Man- 
dar Maju.

Sembiring, Sentosa. 2012. Hukum Perbankan. Edisi Revisi. Bandung: Mandar Maju.

Siamat, Dahlan. 2005. Manajemen Lembaga Keuangan. Jakarta: Lembaga Penerbit Fakultas Ekonomi Universitas Indonesia.

Subekti. 2002. Hukum Perjanjian. Cetakan ke-19. Jakarta: Intermasa.

Susilo, Sri dan Tim. 2000. Bank dan Lembaga Keuangan Lain. Jakarta: Salemba Empat.

\section{Peraturan Perundang-undangan}

Kitab Undang-Undang Hukum Perdata (Burgelijk Wetbook);
Kitab Undang-Undang Hukum Dagang (KUHD)

Undang-Undang Nomor 10 Tahun 1998 tentang Perubahan Undang-Undang Nomor 7 Tahun 1992 Tentang Perbankan

Undang-Undang Nomor 8 Tahun 1999 tentang Perlindungan Konsumen

Peraturan Bank Indonesia Nomor 11/11/ PBI/2009 tentang Penyelenggaraan Kegiatan Alat Pembayaran Dengan Menggunakan Kartu

Peraturan Bank Indonesia Nomor 14/2/ PBI/2012 Tentang Penyelenggaraan Alat Pembayaran Dengan Menggunakan Kartu. 